Article

\title{
Silicon and Plant Growth-Promoting Rhizobacteria Pseudomonas psychrotolerans CS51 Mitigates Salt Stress in Zea mays L.
}

\author{
Happy Anita Appiah Kubi ${ }^{1,+}$, Muhammad Aaqil Khan ${ }^{1,+}{ }^{\circledR}$, Arjun Adhikari ${ }^{1,+}{ }^{\dagger}$, Muhammad Imran ${ }^{1}$, \\ Sang-Mo Kang ${ }^{1}$, Muhammad Hamayun ${ }^{2}$ and In-Jung Lee ${ }^{1, *}$
}

1 Department of Applied Biosciences, Kyungpook National University, Daegu 41566, Korea; happy2020@knu.ac.kr (H.A.A.K.); aqil_bacha@yahoo.com (M.A.K.); xteriousarjun7@gmail.com (A.A.); m.imran02@yahoo.com (M.I.); kmoya@hanmail.net (S.-M.K.)

2 Department of Botany, Abdul Wali Khan University, Mardan, Khyber Pakhtunkhwa 23200, Pakistan; hamayun@awkum.edu.pk

* Correspondence: ijlee@knu.ac.kr; Tel.: +82-53-950-5708; Fax: +82-53-953-6880

+ These authors contributed equally to this work.

\section{check for} updates

Citation: Kubi, H.A.A.; Khan, M.A.; Adhikari, A.; Imran, M.; Kang, S.-M.; Hamayun, M.; Lee, I.-J. Silicon and Plant Growth-Promoting

Rhizobacteria Pseudomonas psychrotolerans CS51 Mitigates Salt Stress in Zea mays L. Agriculture 2021 11, 272. https://doi.org/10.3390/ agriculture11030272

Academic Editor: Ana P. G. C. Marques

Received: 11 February 2021

Accepted: 18 March 2021

Published: 22 March 2021

Publisher's Note: MDPI stays neutral with regard to jurisdictional claims in published maps and institutional affiliations.

Copyright: (c) 2021 by the authors. Licensee MDPI, Basel, Switzerland. This article is an open access article distributed under the terms and conditions of the Creative Commons Attribution (CC BY) license (https:// creativecommons.org/licenses/by/ $4.0 /)$

\begin{abstract}
Salinity is a significant abiotic stress for crop plants and a threat to global food security. Optimizing yield without adversely affecting the ecosystem is necessary for a sustainable agriculture. Silicon and plant growth-promoting bacteria were reported for mitigating several abiotic and biotic stress in plants. In our study, we identified the salt-tolerant rhizobacterium Pseudomonas psychrotolerans CS51. This species produces several plant-growth-promoting biochemicals like indole3 -acetic acid $(33 \pm 1.8 \mathrm{ng} / \mathrm{mL})$ and gibberellic acid (GA3; $38 \pm 1.3$ and GA4; $23 \pm 1.2 \mathrm{ng} / \mathrm{mL}$ ) in Luria-Bertani(LB) media, and LB media spiked with $200 \mathrm{mM} \mathrm{NaCl}$ (indole-3-acetic acid(IAA); $17.6 \pm 0.4 \mathrm{ng} / \mathrm{mL}, \mathrm{GA} 3 ; 21 \pm 0.9$ and GA4; $19 \pm 1.0 \mathrm{ng} / \mathrm{mL})$. In the current study, we aimed to investigate the effect of isolate CS51 and exogenous silicon ( $3 \mathrm{mM})$ on maize under salinity stress $(200 \mathrm{mM})$. Our results showed that the sole application of isolate CS51, Si, and combined CS51 + Si significantly enhanced maize biomass and chlorophyll content under normal and salinity stress. Phytohormonal results showed that salinity stress increased abscisic acid (ABA; three folds) and jasmonic acid (JA; 49.20\%). However, the sole and combined isolate CS51 + Si application markedly reduced ABA (1.5 folds) and JA content (14.89\%). Besides, the sole and isolate CS51 + Si co-application strengthened the antioxidant system, such as flavonoid (97\%) and polyphenol (19.64\%), and lowered the prolineCS51 + Si content $(57.69 \%)$ under $\mathrm{NaCl}$ stress. Similarly, the CS51 and Si inoculation (solely or combined) significantly enhanced the Si uptake (4 folds) and reduced the $\mathrm{Na}^{+}$uptake (42.30\%) in maize plants under $\mathrm{NaCl}$ stress. In conclusion, the current finding suggests that combining CS51 with Si can be used against salinity stress in maize plants and may be commercialized as a biofertilizer.
\end{abstract}

Keywords: salinity stress; isolate CS51 + Si; phytohormones; antioxidants regulation; maize

\section{Introduction}

Salt toxicity in crops due to soil salinization is considered a major global agricultural problem [1,2]. Currently, $8 \%$ of the land area is affected by soil salinization worldwide [3], threatening productivity in irrigated lands up to $20 \%$ by 2050 [4,5]. Furthermore, the salinized area is increasing at a rate of $10 \%$ annually due to native rock weathering, irrigation with saline water, severe usage of mineral fertilizers, low precipitation, poor agriculture practices, and high surface evaporation $[2,6,7]$. Soil salinity inhibits crop productivity by weakening the root growth, decreasing nutrient uptake, and affecting the metabolic process [8-10]. Salinity stress is involved in various morphological, physiological, and metabolic processes that ultimately decrease crop productivity and yield quality [10-12]. Plants that experience salt stress often develop visual injuries affecting lateral shoot development and growth attributes, and clear morphological differences in overall growth and leaf 
morphology are observed between salinity-stressed plants and typical crop plants [13,14]. Similarly, biochemical changes include nutrient imbalance and hormonal interruption (stress hormone: abscisic acid (ABA) and defense hormone: jasmonic acid (JA)); they impair the ability to detoxify reactive oxygen species, activate different antioxidant activities, and decrease photosynthetic activities $[9,14,15]$. High salinity stress accumulates $\mathrm{Na}^{+}$and $\mathrm{Cl}^{-}$between tissues, causing significant intercellular and intracellular ion distribution [15]. Together, all these factors affect plant growth and development, decreasing plants' survival rates and crop productivity and quality [16].

Various mitigation and adaptation approaches, such as salt-tolerant crop plants, leaching of salt from the root zone, microjet irrigation, chemical application, and microbe inoculation, were used to overcome the impact of high soil salinity. The co-application of silicon (Si hereon) and plant growth-promoting bacteria was reported as an environmentally friendly approach for enhancing salinity stress-tolerance in crop plants $[17,18]$. In the Earth's mantel after oxygen, $\mathrm{Si}$ is the most abundant element, constituting up to $27.7 \%$ of the Earth's crust. It occurs naturally in soil, being mainly absorbed as mono-silicic acid, a complex silicate mineral, and most soils contain Si concentration ranging from 14 to $20 \mathrm{mg} / \mathrm{L}$ [19-21]. It is absorbed and released in small amounts in the tissues of large leaves, below $0.5 \%$, and up to $5-10 \%$ in the grass tissues, such as rice, wheat, and maize. $\mathrm{Si}$ may enhance salinity tolerance in plants by improving photosynthetic efficiency, reactive oxygen species (ROS), and scavenging enzyme activity, and by improving $\mathrm{Na}^{+}$and $\mathrm{K}^{+}$ homeostasis [18]. Moreover, halotolerant plant-growth-promoting bacteria (PGPB) plays a vital role in various plants under salinity stress by enhancing plant tolerance and growth Plant-growth-promoting rhizobacteria (PGPR) colonizes near the root rhizosphere and increases plant growth through multiple mechanisms like biosynthesis of phytohormones, exopolysaccharides, and volatile organic compounds [1,22]. Researchers recently reported that PGPB and Si application showed better tolerance to salinity stress and seemed feasible and promising to improve plant growth and yield under salinity stress [18,23,24].

Zea mays L. is an important cereal crop grown under a broad spectrum of soil and climatic conditions worldwide $[25,26]$. It is a critical agricultural crop in food security and sovereignty in a future with water scarcity [27]. Maize feeds many developing countries, mostly in Africa, Asia, and Central America (https://maize.org/why-maize/). It serves as a significant food source for both humans and livestock worldwide [28]. It is also a source of protein $(3.27 \mathrm{~g})$, iron, vitamin B4, carbohydrates ( $18.7 \mathrm{~g}$, fats $(1.35 \mathrm{~g})$, and minerals, as well as an industrial raw material for drugs, starch, and oil extraction [28]. Previously, several researchers reported halotolerant bacteria and $\mathrm{Si}$ for salinity stress mitigation in maize [29-34]. However, little information is available on the combined effect of Si application and plant growth-promoting bacterium on maize under salinity stress. Therefore, the present study aimed to isolate and identify halotolerant plant growth-promoting bacteria with multi-plant growth-promoting traits like phytohormones production in regular LB media and $\mathrm{NaCl}$ stress media (IAA and gibberellic acids (GAs)) and phosphate solubilization. Additionally, it also aimed to investigate the role of separate and co-application of $\mathrm{Si}$ and halotolerant isolate on the growth attribute in maize plant under normal and $\mathrm{NaCl}$ stress. Furthermore, this study also investigated the effect of $\mathrm{Si}$ and bacterial isolate on plant endogenous phytohormones (ABA and JA) and analyzed antioxidant activities and the ion uptake's translocation ( $\mathrm{Na}$ and $\mathrm{Si}$ ) in maize under normal and $\mathrm{NaCl}$ stress.

\section{Materials and Methods}

\subsection{Identification and Selection of Microbes}

Several plant growths promoting rhizobacteria stocked in the Crop Physiology Lab, School of Applied Biosciences, and Kyungpook National University, South Korea were screened for salt resistance test with different concentration (0, 50, 100, 150, 200, 250, and $300)$. The bacteria with higher plant growth-promoting traits like higher salt resistance, IAA production, GA production, and phosphate solubilizing ability were selected for further experimentation. 


\subsection{Biochemical Test of P. physcrotolerans CS51}

\subsubsection{In Vitro IAA and GA Production in Cell-Free Culture}

The isolate was grown in LB media for seven days under control, and $200 \mathrm{mM}$ salt concentration and various biochemical tests were performed with the pure culture. Forty $\mathrm{mL}$ of bacterial culture was taken for each replication, and GA was extracted [35]. Briefly, a one-week-old cell-free culture of bacterial isolate CS51 (only grow in LB media) and isolate CS51 (LB media spiked with $20 \mathrm{mM} \mathrm{NaCl}$ ) was amended with $\left[{ }^{2} \mathrm{H}_{2}\right] \mathrm{GA}$ internal standards. This bacterial isolate was obtained from Prof. Lewis N. Mander, from the Australian National University, Canberra, Australia. The sample was extracted and dried, and the dried samples were carried out for HPLC using a 3.9 $\times 300-\mathrm{m}$ Bondapak C18 column (Waters Crop., Milford, MA, USA). The sample was eluted at $1.0 \mathrm{~mL} / \mathrm{min}$ with the following gradient: $0-5 \mathrm{~min}$, isocratic $28 \%$ methanol in $1 \%$ aqueous acetic acid; 5-35 min, linear gradient from $28 \%$ to $86 \%$ methanol; $35-36 \mathrm{~min}, 86 \%$ to $100 \%$ methanol; $36-40 \mathrm{~min}$, and isocratic $100 \%$ methanol. Forty-eight fractions of $1.0 \mathrm{~mL}$ each were collected. The extracted GA was quantified by injecting into a gas chromatograph coupled to mass spectroscopy (GC-MS, 6890N network GC system, and 5973 network mass selective detector; Agilent Technologies) (Table S1). The method described by Lee [35] was used to detect and quantify the IAA content of the isolated culture. In brief, culture filtrate was vacuum evaporated and the organic layer obtained was subjected to a reverse-phase C18 column. The samples were dried through elution with methanol gradient, and the methyl esters obtained from the sample were re-dissolved in ethyl acetate and analyzed through gas chromatography-mass spectrometry (Table S2). The IAA level was quantified using a standard peak value.

\subsubsection{Phosphate Solubilizing Test}

Twenty $\mu \mathrm{L}$ of the isolate CS51 culture was inoculated on the National Botanical Research Institute's Phosphate (glucose $10 \mathrm{~g} / \mathrm{L}, \mathrm{MgSO}_{4} \cdot 7 \mathrm{H}_{2} \mathrm{O} 0.25 \mathrm{~g} / \mathrm{L}, \mathrm{MgCl}_{2} \cdot 6 \mathrm{H}_{2} \mathrm{O} 5 \mathrm{~g} / \mathrm{L}$, $\left(\mathrm{NH}_{4}\right)_{2} \mathrm{SO}_{4} 0.1 \mathrm{~g} / \mathrm{L}, \mathrm{KCl} 0.2 \mathrm{~g} / \mathrm{L}$, with $\left.0.25 \% \mathrm{Ca}_{3}\left(\mathrm{PO}_{4}\right)_{2}\right)$ and incubated $\left(30{ }^{\circ} \mathrm{C} ; 7\right.$ days). The halo-zone was noted to detect the phosphate solubilizing ability $[5,12]$. Furthermore, bacterial growth was evaluated every $24 \mathrm{~h}$ for 7 days after incubation by measuring both the halo and colony diameter. To measure the diameter of halo zone, the colony diameter was subtracted from the halo [36].

\subsection{Screening Test of Si Impact on Maize}

The Korean hybrid maize variety, O Phi S whiten No.2, from PPS SEED Co., Ltd. (Gyeonggi-do, Korea) with seed registration number: Gyeonggi 10-1997-No. 13-3 51, was used for the experiment. Randomly selected Si doses from 1, 2, 3, and $5 \mathrm{mM}$ were applied on the ten-day-old seedlings of maize for one week. After two weeks and the Si concentration, the morphological characteristics that showed the plant's optimum growth were selected for a further experiment (Table S3).

\subsection{Impact of Si and Isolate CS51 on Maize Plant under Normal and $\mathrm{NaCl}$ Stress}

The experiment was conducted in the Kyungpook National University's greenhouse, at Daegu, under natural light with controlled temperature. The average day temperature was maintained at $26 \pm 4{ }^{\circ} \mathrm{C}$, whereas at night, the temperature was $18 \pm 3^{\circ} \mathrm{C}$. Maize seeds were germinated in a germination tray filled with autoclave horticulture soil $\left(121^{\circ} \mathrm{C}\right.$, $15 \mathrm{~min}$ for three times) [37,38]. After ten days of germination, uniform seedlings were selected and transferred to plastic pots filled with autoclave horticulture soil (200 g per pot). The experiment was conducted in two parts, which were NaCl-stressed and nonstressed conditions (NS). (1) Control: only water, (2) $3 \mathrm{mM} \mathrm{Si}$, (3) bacteria CS51, and (4) co-application of isolate CS51 + Si. Stressed conditions were designed as (5) $200 \mathrm{mM} \mathrm{NaCl}$ stress, (6) $\mathrm{Si}+\mathrm{NaCl},(7)$ isolate $\mathrm{SC} 51+\mathrm{NaCl}$, and (8) co-application of isolate CS51 $+\mathrm{Si}+\mathrm{NaCl}$. A $250 \mathrm{~mL}$ of bacteria culture was grown in LB for $24 \mathrm{~h}$ and centrifuged at $6000 \times \mathrm{g}$ for $10 \mathrm{~min}$ at $4{ }^{\circ} \mathrm{C}$. The pellets obtained were diluted with distilled water to form $10^{8}$ colony forming units per milliliter. Five days after transplanting, $50 \mathrm{~mL}$ of freshly diluted bacterial culture 
and $3 \mathrm{mM} \mathrm{Si}$ was applied for ten days after two days. Next, the plants were treated with $50 \mathrm{~mL}$ of salt solution for ten days after a one-day interval. After the stress of two weeks, the plants' morphological characteristics were noted and harvested, and physiological studies were performed.

\subsection{Quantification of JA and ABA Phytohormones}

The protocol described by $[39,40]$ was used to determine the abscisic acid (ABA hereon). The ABA was extracted from the plants' aerial parts (freeze-dried plant samples, $0.3 \mathrm{~g}$ ), and a chromatograph was run using the Me-[2H6]-ABA standard. The fraction was methylated with diazomethane for detection, and ABA was quantified using GC-MS (6890N network gas chromatography, Agilent Technologies). A software from ThermoQuest Corp., Manchester, UK was used to monitor signal ions $(m / z 162$ and 190 for Me-ABA and $\mathrm{m} / \mathrm{z} 166$ and 194 for Me-[2H6]-ABA) (Table S4). The method described by [41,42] was used to determine the plant's jasmonic acid (JA hereon) content. In brief, a $0.1 \mathrm{~g}$ freezedried ground sample was extracted with acetone: citric acid $(70: 30 v / v)$ and filtered. The [9, 10-2H2] JA standard (100 ng) was added. The solvent was evaporated and washed with $0.1 \mathrm{M}$ potassium phosphate buffer, and $\mathrm{pH}$ was adjusted to 2.5 . The solution was stirred with diethyl-amino cellulose, filtered, and washed with chloroform in a column fixed with sodium sulfate. The extract obtained was injected in GC-MS/SIM (6890N Network GC System and 5973 Network Mass Selective Detector; Agilent Technologies, Santa Clara, CA, USA), and the peaks obtained were noted (Table S4).

\subsection{Antioxidant Enzyme Activities}

For polyphenol content [1], the sample was extracted with $100 \%$ methanol and measured using a spectrophotometer (Shimadzu, Kyoto, Japan) at $750 \mathrm{~nm}$. For flavonoid content, sample extracts were mixed with double distilled water and added $5 \% \mathrm{NaNO}_{2}$ $(30 \mu \mathrm{L})$. After $5 \mathrm{~min}, 10 \%$ of $60 \mu \mathrm{L}$ of $\mathrm{AlCl}_{3}$ and $1 \mathrm{M} \mathrm{NaOH}$ was added and vortexed. The absorbance reading was taken at $500 \mathrm{~nm}$ using a spectrophotometer [43]. Total proline content was used with minor modification [41]. Proline (Sigma Aldrich, St. Louis, MO, USA; $2,4,6,8$, and $10 \mu \mathrm{g} / \mathrm{mL}$ ) was measured to construct a standard curve. The absorbance was measured at $520 \mathrm{~nm}$ using a spectrophotometer.

\subsection{Determination of Si and Na Uptake in Plant}

Both the $\mathrm{Si}$ and $\mathrm{Na}^{+}$contents, the maize plant's shoot treated with $\mathrm{Si}$, isolate CS51, and the isolate CS51 + Si co-application under normal and $\mathrm{NaCl}$ stress conditions were investigated [44] by using inductively coupled plasma mass spectrometry (ICP-MS; Optime 7900DV, Perkin-Elmer, Waltham, MA, USA). Briefly, freeze-dried shoot samples were used to digest $0.05 \mathrm{~g}$ of sample with $7 \mathrm{~mL}$ of $65 \% \mathrm{NHO}_{3}$ and $1 \mathrm{~mL}$ of $30 \% \mathrm{H}_{2} \mathrm{O}_{2}$ and kept in digestion microwave $\left(180^{\circ} \mathrm{C} ; 20 \mathrm{~min}\right)$, and it cooled for $40 \mathrm{~min}$. The obtained solvent was quantified using inductively coupled plasma mass spectrometry (ICP-MS; Optima 7900DV, Perkin-Elmer, Waltham, MA, USA) [45].

\subsection{Statistical Analysis}

The current study was performed in a completely randomized design. In the plant experiment, each treatment had eight replications. The statistical analysis was performed by Duncan's multiple range test using proc GLM in SAS version 9.2 (Cary, NC, USA), and graphs were constructed using GraphPad Prism software. All values are presented as the mean \pm standard deviation of three replicates.

\section{Results}

\subsection{Isolate CS51's Screening and Identification}

Different plant growth-promoting rhizospheric bacterial stocks were collected from the Crop Physiology Lab, grown on LB agar plate, and screened for different PGP traits and salt tolerance. The isolate CS51 showed phosphate solubilizing activity (Figure S1) 
and tolerance to $\mathrm{NaCl}$ stress. Therefore, it was used to investigate the molecular identification by amplifying and sequencing the 16S rRNA and BLAST search tool of NCBI database/EzTaxon. Our results revealed that isolate CS51 exhibited a high sequence identity with Pseudomonas psychrotolerans NCBI GenBank accession no CP021645 (Figure 1).

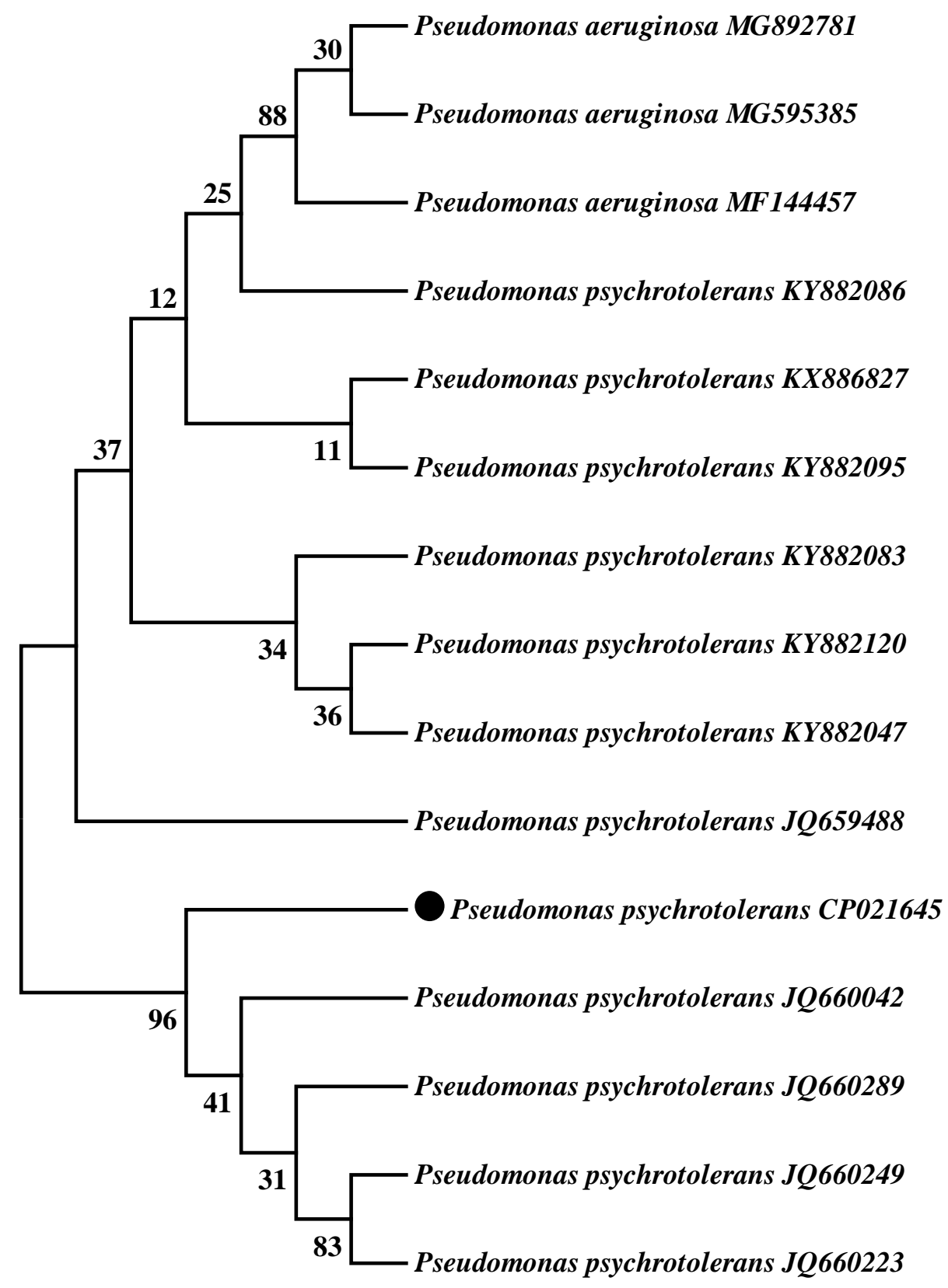

Figure 1. Phylogenetic analysis of Pseudomonas psychrotolerans CS51 with NCBI accession number CP021645.

\subsection{In Vitro IAA and GAs Production in $\mathrm{NaCl}$ Stress}

The isolate CS51's culture filtrate was evaluated to determine its ability to secreted IAA and GAs in LB medium and $\mathrm{NaCl}$ stress LB medium. The IAA results showed that isolate CS51 secreted a higher concentration of IAA (33 $\pm 1.8 \mathrm{ng} / \mathrm{mL})$, as well as in $\mathrm{LB}$ media spiked with $\mathrm{NaCl}(17.6 \pm 0.4 \mathrm{ng} / \mathrm{mL})$ (Figure 2A). Similarly, the GAs results showed that different bioactive GAs were observed in the isolate CS51's culture filtrate using a GC/MS selection ion monitor. The GA3 was more predominantly detected $(38 \pm 1.3 \mathrm{ng} / \mathrm{mL})$ than GA4 $(23 \pm 1.2 \mathrm{ng} / \mathrm{mL})$. Similarly, the isolate CS51 also secretes 
bioactive GA3 $(21 \pm 0.9 \mathrm{ng} / \mathrm{mL})$ and GA4 $(19 \pm 1.0 \mathrm{ng} / \mathrm{mL})$ under NaCl-spiked media (Figure 2B).





Figure 2. Amount of indole-3-acetic acid IAA (A) and gibberellic acid (GA) production (B) in culture broth of isolate CS51 in regular Luria-Bertani(LB) media and LB media spiked with $\mathrm{NaCl}$. Each value represents the mean $\pm \mathrm{SD}$ of three replicates. Different letters on columns with error bars (mean $\pm \mathrm{SD}$ ) represent a significant difference among the treatments evaluated by Duncan's Multiple Range Test (DMRT).

\subsection{Isolate CS51 and Si Ameliorative Effects on Maize Growth under Salinity Stress}

Our study's results showed that plant growth features were significantly affected by salinity stress. However, the isolate CS51 + Si co-application enhanced salinity stress promoted the growth attributes and the biochemical parameters (Table 1; Figure 3). Our results showed that under normal growth conditions, application of isolate SC51, $\mathrm{Si}$, and the isolate CS51 + Si co-application significantly enhanced the shoot length (13.39-20.69\%), root length (23.64-44.59\%), shoot fresh weight (10.56-44.68\%), root fresh weight (10.56-44.68\%), and chlorophyll content (11.89-22.08\%) when compared with control plants. When maize plants were subjected to salinity stress, we observed significant decreases in shoot length (21.07\%), root length $(38.35 \%)$, shoot, and root fresh weight (42.69 and $38.17 \%)$, and chlorophyll content $(52.77 \%)$ compared with control plants. However, when the NaCl-stressed maize plants were treated with the co-application of isolate CS51 + Si, significant increases in shoot length $(49.10 \%)$, root length $(109.20 \%)$, shoot and root fresh weights $(68.58$ and $55.02 \%)$, and chlorophyll (74.06\%) content were observed compared with $\mathrm{NaCl}$-stressed plants treated solely with isolate CS51 or Si (Table 1; Figure 3). 
Table 1. The effect of isolate CS51, Si, and co-application of isolate CS51 + Si on the growth, biomass, and chlorophyll content of maize plants under normal and $\mathrm{NaCl}$ stress $(200 \mathrm{mM})$. Each value represents the mean $\pm \mathrm{SD}$ of three replicates. Values in a column followed by different letters are significantly different as evaluated by Duncan's Multiple Range Test (DMRT).

\begin{tabular}{|c|c|c|c|c|c|c|}
\hline Treatment & $\begin{array}{c}\text { Chlorophyll } \\
\mathrm{mg} / \mathrm{m}^{-2}\end{array}$ & $\begin{array}{c}\text { Root Weight } \\
\text { (g) }\end{array}$ & $\begin{array}{c}\text { Shoot Weight } \\
\text { (g) }\end{array}$ & $\begin{array}{l}\text { Root Length } \\
\text { (cm) }\end{array}$ & $\begin{array}{l}\text { Shoot Length } \\
\text { (cm) }\end{array}$ & $\begin{array}{l}\text { Diameter } \\
(\mathrm{cm})\end{array}$ \\
\hline \multicolumn{7}{|c|}{ Normal condition } \\
\hline Control & $288.67 \pm 17.04^{b c}$ & $15.53 \pm 1.11^{\mathrm{c}}$ & $15.53 \pm 1.01^{b}$ & $22.10 \pm 0.46^{b}$ & $72.84 \pm 12.09^{c}$ & $14.53 \pm 0.80^{b}$ \\
\hline Bac & $323 \pm 1.73^{a b}$ & $17.17 \pm 0.75^{b c}$ & $18.3 \pm 0.75^{\mathrm{b}}$ & $18.3 \pm 1.17^{\mathrm{a}}$ & $69.93 \pm 1.01^{b}$ & $13.93 \pm 0.93^{b}$ \\
\hline $\mathrm{Si}$ & $285.67 \pm 6.51^{c}$ & $17.63 \pm 1.27^{\mathrm{b}}$ & $17.17 \pm 1.27^{\mathrm{b}}$ & $17.3 \pm 1.67 \mathrm{c}$ & $72.57 \pm 0.59^{b}$ & $15.37 \pm 1.14^{b}$ \\
\hline $\mathrm{Si}+\mathrm{Bac}$ & $352.33 \pm 32.87^{a}$ & $22.47 \pm 0.74^{\mathrm{a}}$ & $22.47 \pm 0.74^{\mathrm{a}}$ & $24.4 \pm 1.04 \mathrm{~b}$ & $74.43 \pm 1.18^{\mathrm{a}}$ & $17.43 \pm 1.31^{\mathrm{a}}$ \\
\hline \multicolumn{7}{|c|}{ Salinity stress } \\
\hline $\mathrm{NaCl}(200 \mathrm{mM})$ & $136.33 \pm 10.21^{c}$ & $9.6 \pm 1.15^{c}$ & $8.9 \pm 0.66^{b}$ & $15.13 \pm 0.25^{d}$ & $48.67 \pm 4.91^{\mathrm{c}}$ & $8.27 \pm 0.61^{a}$ \\
\hline $\mathrm{NaCl}+\mathrm{Bac}$ & $202.33 \pm 12.0^{b}$ & $12.57 \pm 1.43^{b}$ & $12.3 \pm 1.08^{b}$ & $18.03 \pm 0.95^{c}$ & $61.57 \pm 0.61^{\mathrm{b}}$ & $10.97 \pm 1.56^{b}$ \\
\hline $\mathrm{Si}+\mathrm{NaCl}$ & $210 \pm 8.9^{b}$ & $12.56 \pm 1.16^{\mathrm{b}}$ & $10.75 \pm 0.70^{b}$ & $17.10 \pm 0.95^{\mathrm{a}}$ & $62.57 \pm 0.59^{b}$ & $10.57 \pm 1.20^{b}$ \\
\hline $\mathrm{Si}+\mathrm{Bac}+\mathrm{NaCl}$ & $237.3 \pm 8.33^{a}$ & $14.9 \pm 0.3^{a}$ & $14.10 \pm 0.69^{a}$ & $19.80 \pm 0.95^{b}$ & $65.67 \pm 1.59^{a}$ & $13.63 \pm 0.80^{\mathrm{c}}$ \\
\hline
\end{tabular}

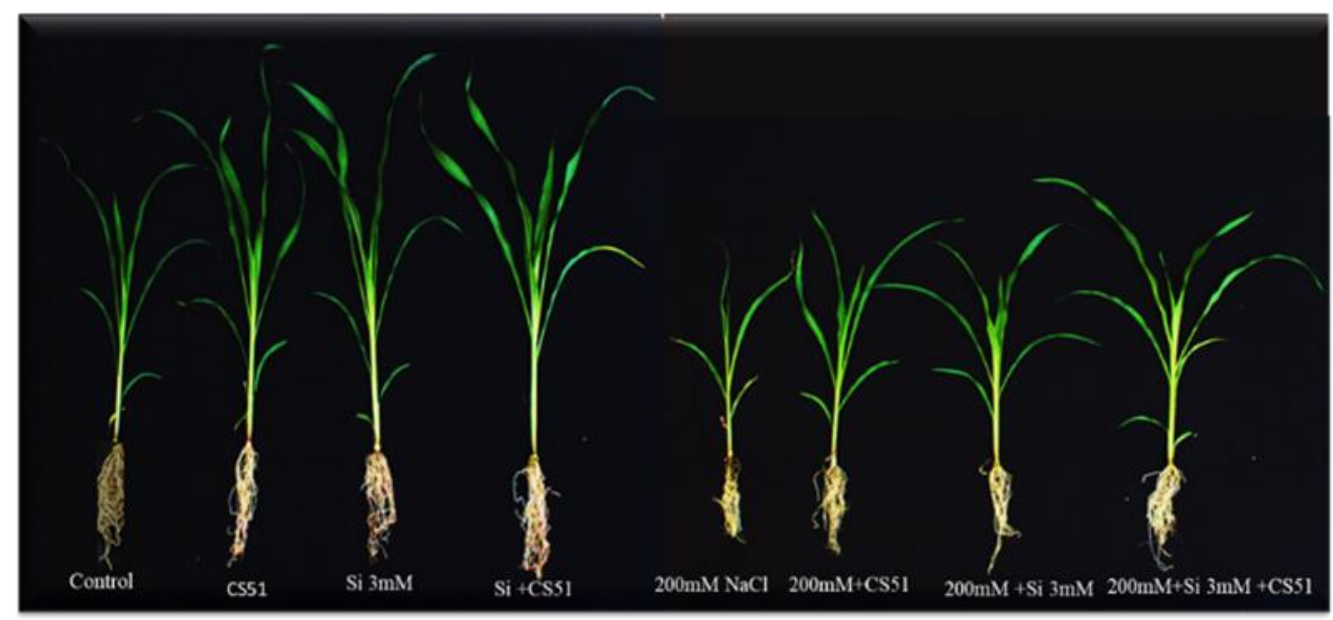

Figure 3. Effects of selected rhizospheric and endophytic bacterial isolate on maize plant growth attributes under $\mathrm{NaCl}$ concentration $(200 \mathrm{mM})$.

\subsection{Isolate CS51 + Si Effects on Endogenous Plant Phytohormones}

Endogenous ABA and JA were investigated in maize plants treated with CS51, Si, and isolate CS51 + Si co-application under normal and NaCl-stressed conditions (Figure 4A). The ABA results showed no significant difference in maize plants' contents from the control treatment and the sole applications of CS51, Si, and the isolate CS51 + Si co-application under normal conditions. However, in NaCl-stressed maize plants, a three-fold increase in ABA content was observed (Figure 4A). In contrast, maize plants treated with sole SC51, Si, and the isolate CS51 + Si co-application markedly reduced the ABA content by 1.5 folds. Similarly, when both control and $\mathrm{NaCl}$-stressed maize plants were subjected to JA analysis, there was a significant increase in JA content from NaCl-stressed plants (49.20\%). However, maize plants treated with the isolate CS51 + Si co-application significantly decreased JA content $(14.89 \%)$ compared to the $\mathrm{NaCl}$-stressed control maize plant (Figure 4B). 

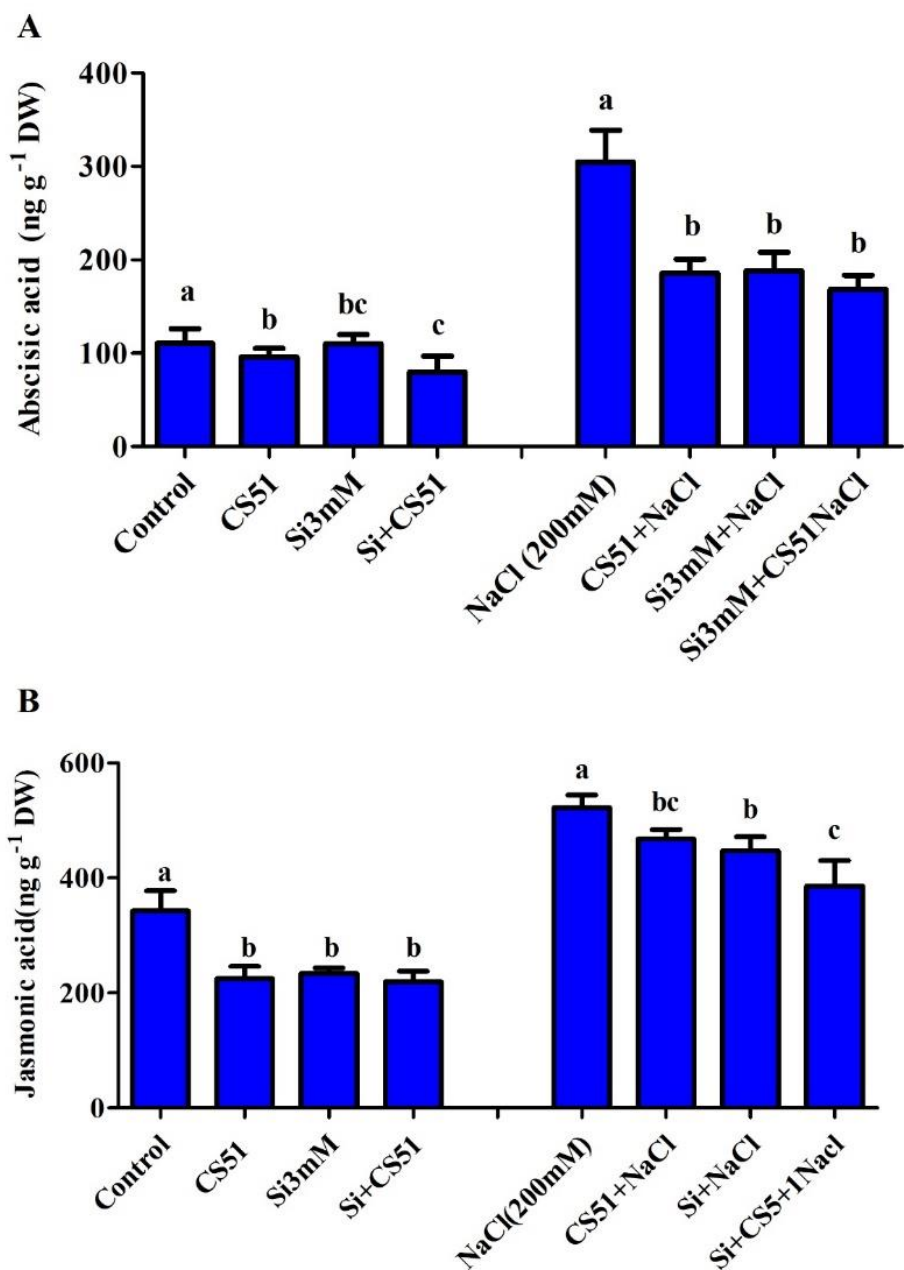

Figure 4. Effect of strain isolate CS51 and Si on (A) abscisic acid (ABA) contents and (B) jasmonic acid (JA) contents of maize plants grown under elevated $\mathrm{NaCl} 200 \mathrm{mM}$. Each value represents the mean \pm SD of three replicates. Different letters on columns with error bars (mean \pm SD) represent a significant difference among the treatments evaluated by Duncan's Multiple Range Test (DMRT).

\subsection{Isolate CS51 and Si Effects on Maize Antioxidant}

Different antioxidants, such as proline, polyphenol, and flavonoid content, were investigated for normal and $\mathrm{NaCl}$ stress in maize plants treated with sole CS51, $\mathrm{Si}$, and the isolate CS51 + Si co-application (Figure 5). The polyphenol, flavonoids, and proline content showed no significant or slight difference under normal conditions (Figure 5). However, the flavonoids and polyphenol contents decreased under $\mathrm{NaCl}$ stress (37.93\% and 26.31\%). On the other hand, plants solely treated with isolate CS51, Si, and the isolate CS51 + Si co-application significantly enhanced flavonoids (86\% to $97 \%$ ) and polyphenol content (7.14\% to $19.64 \%$ ) (Figure 5B,C). In contrast to flavonoid and polyphenol, proline content significantly increased under salinity stress (138\%) compared with control maize plants (Figure 5A). However, the sole application of isolate SC51, Si, and the isolate CS51 + Si co-application remarkably reduced the proline content $(19.23 \%$ to $57.69 \%)$ compared with plants under salinity stress (Figure 5A). 




B
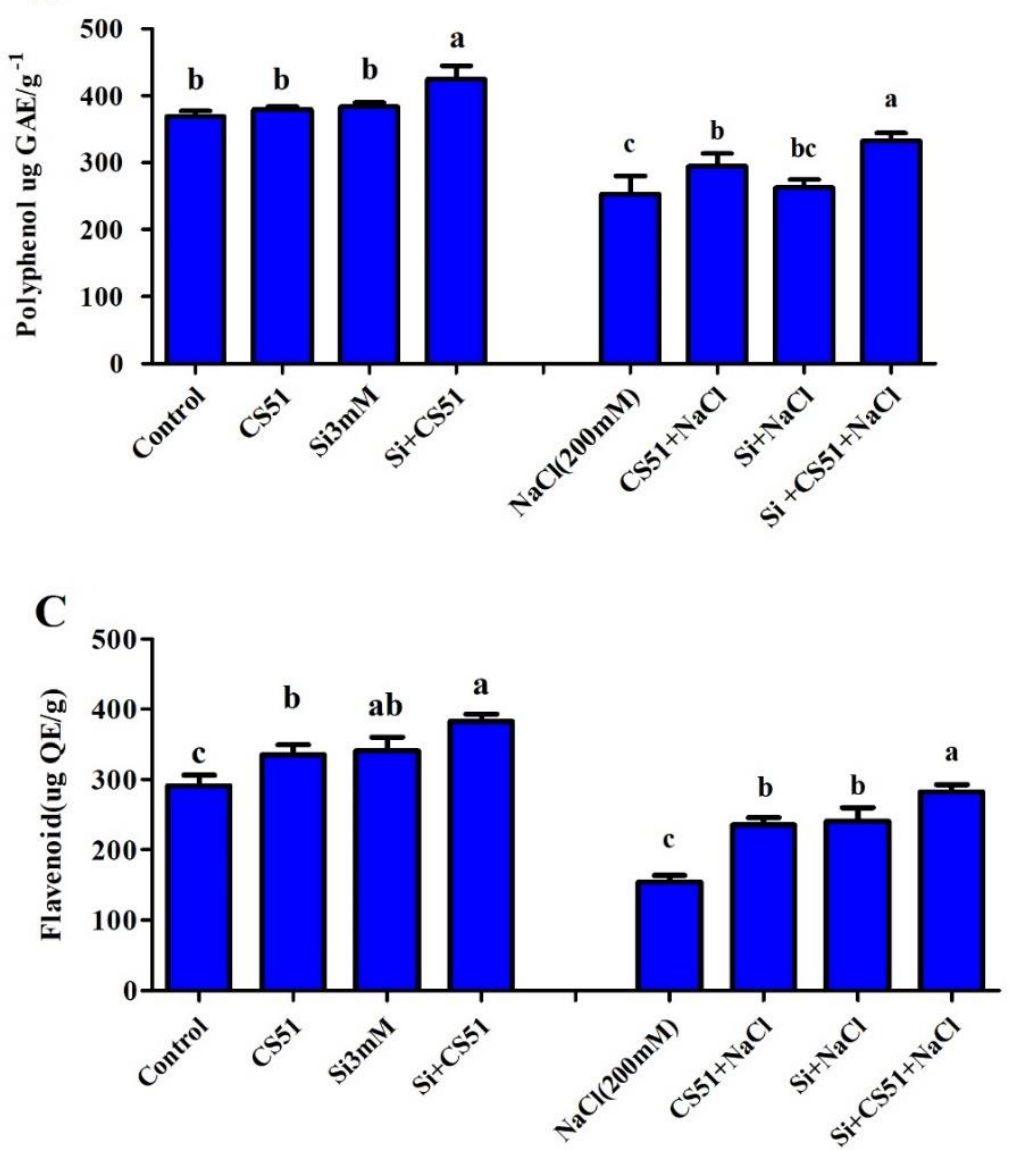

Figure 5. Quantification of (A) proline content, (B) polyphenol oxidase (PPO), and (C) flavonoid content of maize grown in elevated $\mathrm{NaCl}(200 \mathrm{mM})$ treated with isolate CS51 and Si. Each value represents the mean \pm SD of three replicates. Different letters on columns with error bars (mean \pm SD) represent a significant difference among the treatments evaluated by Duncan's Multiple Range Test (DMRT).

\subsection{The Bacterial Isolates CS51 and Si Roles in Ion Uptake during Salinity Stress}

The Si ICP results showed that under salinity stress conditions, isolate CS51, Si, and the isolate CS51 + Si co-application significantly enhanced the Si content four folds compared to control NaCl-stressed plants (Figure 6B). On the other hand, $\mathrm{Na}^{+}$content showed no difference under normal conditions (Figure 6A). However, the $\mathrm{NaCl}$ stress application enhanced the $\mathrm{Na}^{+}$uptake $(85.75 \%)$ compared with control normal plants. The sole application of isolate SC51, $\mathrm{Si}$, and the isolate CS51 + Si co-application significantly 
mitigated salinity stress and decreased $\mathrm{Na}^{+}$uptake (30.76-42.30\%) compared with $\mathrm{NaCl}-$ stressed maize plants (Figure 6A).
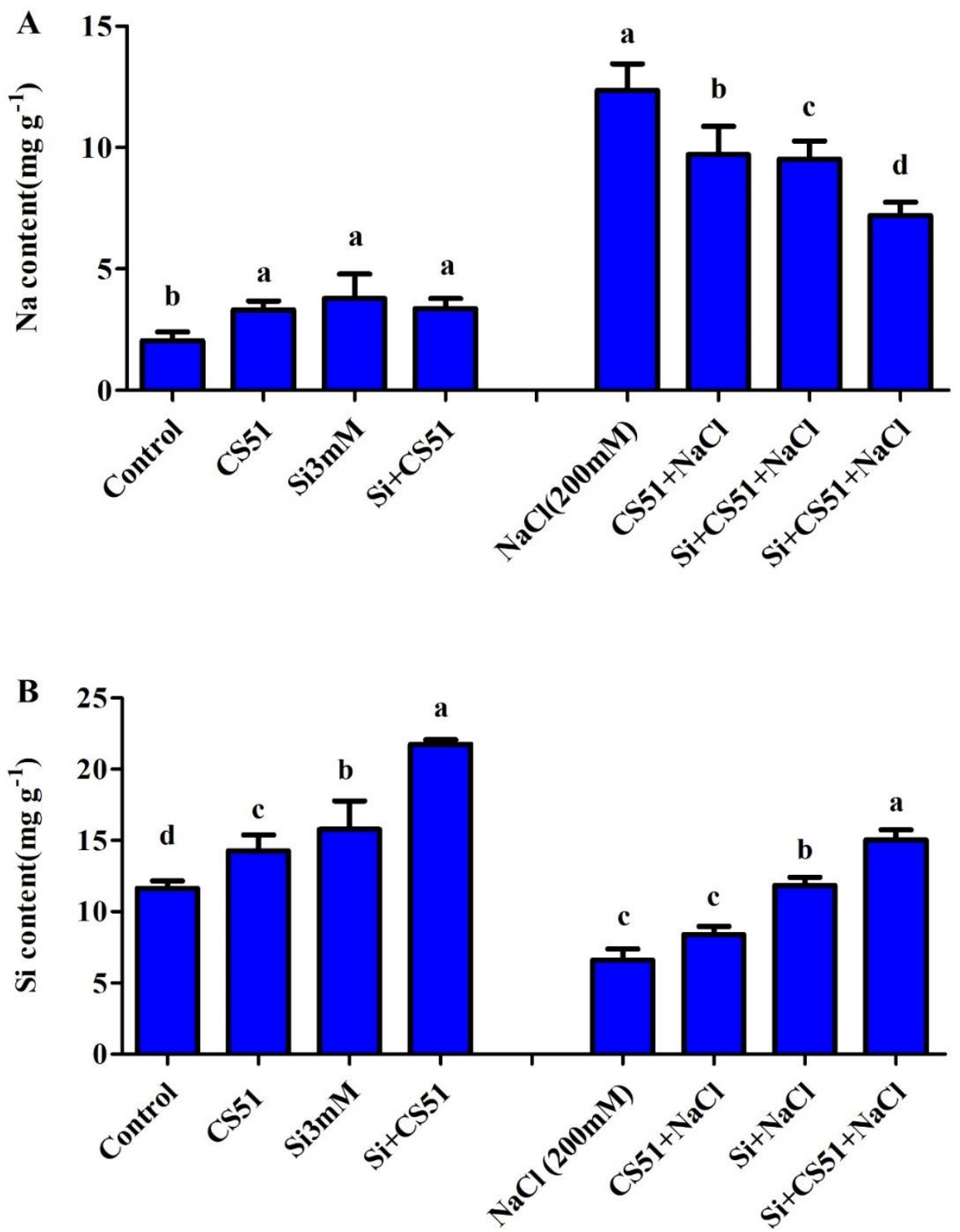

Figure 6. Inductively coupled plasma mass spectrometry (ICP) analysis of (A) $\mathrm{Na}^{+}$content and (B) Si content of maize grown in elevated $\mathrm{NaCl}(200 \mathrm{mM})$ treated with isolate CS51 and Si. Each value represents the mean $\pm \mathrm{SD}$ of three replicates. Different letters on columns with error bars (mean $\pm \mathrm{SD}$ ) represent a significant difference among the treatments evaluated by Duncan's Multiple Range Test (DMRT).

\section{Discussion}

Soil salinization is a severe agronomic threat to sustainable crop production since it reduces important cereal crops' yield, such as the yield of wheat, rice, and corn [46]. Plants under salinity stress undergo several morphological and physiological changes that impede their growth and development. In general, salinity stresses affect plants' metabolism through ionic toxicity and nutrient imbalance that impose high osmotic and oxidative stress and, ultimately, reduce photosynthetic rates and yield [46]. Several strategies were formulated to alleviate salt stress's detrimental effects in plants, such as Si and halotolerant 
plant growth-promoting bacteria $[24,47,48]$. Here, we discuss how Si and plant growth's combined effect promoting rhizobacteria CS51 augment the Zea mays physiology under salt stress. In this study, our results revealed that salinity stress inhibits plant growth and development. However, the application of exogenous Si and halotolerant isolate CS51 markedly alleviated the salinity stress's adverse effect in maize (Table 1; Figure 3). The selected bacterial isolate CS51's beneficial effects on maize plants were likely due to plant growth-promoting traits, such as salinity tolerance, phosphate solubilization, and phytohormone production (IAA and GA). Gibberellin-producing bacteria enhance various crops' growth and development under normal and salinity stress conditions $[9,10]$. Similarly, IAA is a critical phytohormone, and numerous studies demonstrated that IAA producing halotolerant bacteria improves salinity tolerance $[5,12]$. In this study, isolate CS51 could produce IAA and bioactive and non-bioactive GAs (Figure 2). Therefore, the maize plants' growth promotion under salinity might be mediated by these PGP traits.

Endogenous phytohormones, such as ABA and JA, play a crucial role in signaling in plants to confer tolerance when exposed to stresses. The ABA, also known as the stress hormone, is actively involved in various physiological processes, such as active chemical signals, which contribute to stomatal closure and water conservation [49-51]. The application of exogenous $\mathrm{Si}$ and plant-microbe interaction has been previously reported to mitigate the adverse effects of abiotic stress in plants through reducing ABA levels [52,53]. Our study's results showed that the co-application of exogenous Si and halotolerant isolate CS51 enhanced plant growth parameters and mitigated salinity stress by reducing ABA accumulation (Figure 4A). Similarly, phytohormone JA was reported to play a crucial role in alleviating abiotic stresses in plants [6] by stimulating signal molecules and protecting the plants from oxidative stress and ROS generation [6,54]. In this study, higher endogenous JA levels were observed in maize plants under salinity stress (Figure 4B). However, the co-application of exogenous Si and halotolerant isolate SC51 significantly reduced the JA content in maize plants (Figure 4B). Our results are in line with those from Asaf et al. [36] and Kiribuchi et al. [55]. The inoculation of plant growth-promoting bacteria and $\mathrm{Si}$ significantly dropped the JA content in rice and soybean under stress. Our findings also support previous studies that co-applied exogenous $\mathrm{Si}$ and bacterial inoculation with reduced endogenous JA levels and enhanced plants' growth attributes under abiotic stress $[14,37]$.

Higher $\mathrm{Na}^{+}$accumulation in plant tissue stimulates ROS generation, which causes cellular toxicity [55]. Plants acquire several strategies to neutralize ROS's adverse effects by strengthening antioxidants like catalase and other antioxidant enzymes, such as PPO and POD, to protect the plants against cellular stress, scavenge excess ROS, and remove free radicals. Maize plants treated with Si and isolate CS51 exhibited an increase in flavonoid and polyphenol content and decreased content under salinity stress (Figure 5). Similar results were reported using exogenous $\mathrm{Si}$ and bacterial inoculation, which significantly increased the activity of different ROS-scavenging enzymes in maize, basil, and rice [56-58]. Salinity stress leads to the accumulation of $\mathrm{Na}^{+}$and $\mathrm{Cl}$, which affects other vital elements' assimilation and distribution in plants, altering plant's metabolism and inhibiting growth. Moreover, the higher $\mathrm{Na}^{+}$accumulation in plant cells causes osmotic stress, downregulates the intercellular $\mathrm{K}^{+}$influx, and disrupts homeostasis. Our study's results showed an increase in $\mathrm{Na}^{+}$content under salinity stress (Figure 6). However, the co-application of exogenous $\mathrm{Si}$ and bacterial inoculation decreased $\mathrm{Na}^{+}$uptake in maize plants under salinity stress (Figure 6).

The Si neutralizes ROS produced in plants under salt stress by regulating antioxidant enzyme activity and hormonal system [59]. However, Si uptake in a plant is challenging in crops due to plants' low uptake ability [60]. Our study's external co-application of $\mathrm{Si}$ with rhizobacterium CS51 significantly improved the Si uptake and enhanced the plant morphological attributes and internal physiology (Figure 6). The Ca, P, and K elements were also considerably higher, and low $\mathrm{Na}^{+}$was detected in combined treated Si and CS51 plant shoots. Our results are in line with Adhikari [1], who showed that rhizobacterium 
significantly improved the Si uptake and mitigated the salt stress in plants. Moreover, our results agree with Waqas [61], who elucidated salt-tolerant bacteria's role in maintaining the plants' ionic homeostasis. The possible maintenance of $\mathrm{Na}^{+}, \mathrm{Ca}^{+}$, and $\mathrm{K}^{+}$might have regulated the mineral absorption and promoted the plant's growth.

\section{Conclusions}

In the present study, isolate CS51 was screened as a salinity tolerant with PGP traits (IAA, GAs, and phosphate solubilization) and the combined effect of isolate CS51 and $\mathrm{Si}$ application under salinity stress was invesyigated. Maize plant treated with $\mathrm{Si}$ and CS51 affected the $\mathrm{Na}^{+}$and $\mathrm{Si}$ uptake and favors the plant growth under salinity stress. The application of Si and CS51 enhanced maize growth, chlorophyll content antioxidant activities, reduced $\mathrm{Na}^{+}$uptake, and enhanced Si uptake. Therefore, the current findings reveal a new insight for an integrated approach of mitigating several abiotic and biotic stresses in diverse crops. We believe the isolate CS51 could be a potential candidate for biofertilizer to enhanced plant growth and reduce stress.

Supplementary Materials: The following are available online at https:/ /www.mdpi.com/2077-0 472/11/3/272/s1, Figure S1: (A) Phosphate solubilizing activities of isolate SC51 on NBRIP plates inoculated for 7 days at $30^{\circ} \mathrm{C}$. (B) the clarification halosshow $\mathrm{P}$ solubilization and maximum size of the clarification halos was reached after 7 days. Value given are the mean of three replicate with error bar indicate standard deviations, Table S1: GC/MS-SIM conditions used for analysis and quantification of the Gas, Table S2: C/MS-SIM conditions used for analysis and quantification of IAA, Table S3: Screening test of Si impact on maize with different concentrations of $\mathrm{Si}(1 \mathrm{mM}, 2 \mathrm{mM}$, and 3.mM), Table S4: GC/MS-SIM conditions used for analysis and quantification of the ABA and JA.

Author Contributions: Conceptualization, A.A. and S.-M.K.; methodology, M.I.; software, M.A.K.; formal analysis, H.A.A.K. and A.A.; investigation, H.A.A.K.; resources, I.-J.L.; data curation, H.A.A.K.; writing-original draft preparation, M.A.K.; writing—review and editing, M.H.; visualization, M.A.K.; supervision, I.-J.L.; project administration, I.-J.L.; funding acquisition, I.-J.L. All authors have read and agreed to the published version of the manuscript.

Funding: This research was funded by National Research Foundation of Korea (NRF) funded by the Ministry of Education, grant number 2017R1D1A1B04035601.

Institutional Review Board Statement: Not applicable.

Informed Consent Statement: Not applicable.

Data Availability Statement: Not applicable.

Conflicts of Interest: The authors declare no conflict of interest.

\section{References}

1. Adhikari, A.; Khan, M.A.; Lee, K.E.; Kang, S.M.; Dhungana, S.K.; Bhusal, N.; Lee, I.J. The halotolerant rhizobacterium-pseudomonas koreensis mu2 enhances inorganic silicon and phosphorus use efficiency and augments salt stress tolerance in soybean (Glycine max L.). Microorganisms 2020, 8, 1256. [CrossRef]

2. Kamran, M.; Parveen, A.; Ahmar, S.; Malik, Z.; Hussain, S.; Chattha, M.S.; Saleem, M.H.; Adil, M.; Heidari, P.; Chen, J.T. An overview of hazardous impacts of soil salinity in crops, tolerance mechanisms, and amelioration through selenium supplementation. Int. J. Mol. Sci. 2019, 21, 148. [CrossRef]

3. Etesami, H.; Beattie, G.A. Mining halophytes for plant growth-promoting halotolerant bacteria to enhance the salinity tolerance of non-halophytic crops. Front. Microbiol. 2018, 9, 148. [CrossRef] [PubMed]

4. Hussain, S.; Shaukat, M.; Ashraf, M.; Zhu, C.; Jin, Q.; Zhang, J. Salinity stress in arid and semi-arid climates: Effects and management in field crops. Clim. Chang. Agric. 2019, 12, 123-145. [CrossRef]

5. Khan, M.A.; Asaf, S.; Khan, A.L.; Adhikari, A.; Jan, R.; Ali, S.; Imran, M.; Kim, K.M.; Lee, I.J. Plant growth-promoting endophytic bacteria augment growth and salinity tolerance in rice plants. Plant Biol. 2020, 22, 850-862. [CrossRef] [PubMed]

6. Khan, M.A.; Asaf, S.; Khan, A.L.; Ullah, I.; Ali, S.; Kang, S.M.; Lee, I.J. Alleviation of salt stress response in soybean plants with the endophytic bacterial isolate Curtobacterium sp. SAK1. Ann. Microbiol. 2019, 69, 797-808. [CrossRef]

7. Shrivastava, P.; Kumar, R. Soil salinity: A serious environmental issue and plant growth promoting bacteria as one of the tools for its alleviation. Saud. J. Biol. Sci. 2015, 22, 123-131. [CrossRef] [PubMed] 
8. Chung, Y.S.; Kim, K.S.; Hamayun, M.; Kim, Y. Silicon confers soybean resistance to salinity stress through regulation of reactive oxygen and reactive nitrogen species. Front. Plant Sci. 2019, 10, 1725. [CrossRef]

9. Yoon, J.Y.; Hamayun, M.; Lee, S.K.; Lee, I.J. Methyl jasmonate alleviated salinity stress in soybean. J. Crop Sci. Biotechnol. 2009, 12, 63-68. [CrossRef]

10. Hamayun, M.; Khan, S.A.; Khan, A.L.; Shinwari, Z.K.; Hussain, J.; Sohn, E.Y.; Kang, S.-M.; Kim, Y.H.; Khan, M.A.; Lee, I.J. Effect of salt stress on growth attributes and endogenous growth hormones of soybean cultivar Hwangkeumkong. Pak. J. Bot. 2010, 42, 3103-3112.

11. Khan, M.A.; Asaf, S.; Khan, A.L.; Jan, R.; Kang, S.M.; Kim, K.M.; Lee, I.J. Rhizobacteria AK1 remediates the toxic effects of salinity stress via regulation of endogenous phytohormones and gene expression in soybean. Biochem. J. 2019, 476, 2393-2409. [CrossRef]

12. Khan, M.A.; Asaf, S.; Khan, A.L.; Adhikari, A.; Jan, R.; Ali, S.; Imran, M.; Kim, K.M.; Lee, I.J. Halotolerant Rhizobacterial Strains Mitigate the Adverse Effects of $\mathrm{NaCl}$ Stress in Soybean Seedlings. BioMed Res. Int. 2019, 2019. [CrossRef] [PubMed]

13. Tavakkoli, E.; Rengasamy, P.; McDonald, G.K. High concentrations of $\mathrm{Na}+$ and $\mathrm{Cl}$-ions in soil solution have simultaneous detrimental effects on growth of faba bean under salinity stress. J. Exp. Bot. 2010, 61, 4449-4459. [CrossRef] [PubMed]

14. Khan, M.A.; Ullah, I.; Waqas, M.; Hamayun, M.; Khan, A.L.; Asaf, S.; Kang, S.M.; Kim, K.M.; Jan, R.; Lee, I.J. Halo-tolerant rhizospheric Arthrobacter woluwensis AK1 mitigates salt stress and induces physio-hormonal changes and expression of GmST1 and GmLAX3 in soybean. Symbiosis 2019, 77, 9-21. [CrossRef]

15. Gupta, B.; Huang, B. Mechanism of salinity tolerance in plants: Physiological, biochemical, and molecular characterization. Int. J. Genom. 2014, 2014. [CrossRef]

16. Carillo, P.; Annunziata, M.G.; Pontecorvo, G.; Fuggi, A.; Woodrow, P. Salinity stress and salt tolerance. Abiotic Stress Plants-Mech. Adapt. 2011, 1, 21-38.

17. Khan, A.; Khan, A.L.; Muneer, S.; Kim, Y.H.; Al-Rawahi, A.; Al-Harrasi, A. Silicon and salinity: Crosstalk in crop-mediated stress tolerance mechanisms. Front. Plant Sci. 2019, 10, 1429. [CrossRef]

18. Al-Garni, S.M.S.; Khan, M.M.A.; Bahieldin, A. Plant growth-promoting bacteria and silicon fertilizer enhance plant growth and salinity tolerance in Coriandrum sativum. J. Plant Interact. 2019, 14, 386-396. [CrossRef]

19. Farooq, M.A.; Dietz, K.J. Silicon as versatile player in plant and human biology: Overlooked and poorly understood. Front. Plant Sci. 2015, 6, 994. [CrossRef]

20. Vivancos, J.; Labbé, C.; Menzies, J.G.; Bélanger, R.R. Silicon-mediated resistance of Arabidopsis against powdery mildew involves mechanisms other than the salicylic acid (SA)-dependent defence pathway. Mol. Plant Pathol. 2015, 16, 572-582. [CrossRef] [PubMed]

21. Zargar, S.M.; Mahajan, R.; Bhat, J.A.; Nazir, M.; Deshmukh, R. Role of silicon in plant stress tolerance: Opportunities to achieve a sustainable cropping system. 3 Biotech 2019, 9, 73. [CrossRef]

22. Kim, Y.N.; Khan, M.A.; Kang, S.M.; Hamayun, M.; Lee, I.J. Enhancement of Drought-Stress Tolerance of Brassica oleracea var. italica L. by Newly Isolated Variovorax sp. YNA59. J. Microbiol. Biotechnol. 2020, 10, 1500-1509. [CrossRef]

23. Mahmood, S.; Daur, I.; Al-Solaimani, S.G.; Ahmad, S.; Madkour, M.H.; Yasir, M.; Hirt, H.; Ali, S.; Ali, Z. Plant growth promoting rhizobacteria and silicon synergistically enhance salinity tolerance of mung bean. Front. Plant Sci. 2016, 7, 876. [CrossRef]

24. Etesami, H. Can interaction between silicon and plant growth promoting rhizobacteria benefit in alleviating abiotic and biotic stresses in crop plants? Agric. Ecosyst. Environ. 2018, 253, 98-112. [CrossRef]

25. Farooq, M.; Hussain, M.; Wakeel, A.; Siddique, K.H.M. Salt stress in maize: Effects, resistance mechanisms, and management. A review. Agron. Sust. Develop. 2015, 35, 461-481. [CrossRef]

26. Khan, M.A.; Ullah, A.; Badshah, L.; Hamayun, M. Ethnobotanical and ecological characteristics of weeds growing in the maize fields at Chaghar Matti, district Peshawar. Pak. J. Weed Sci. Res. 2017, 23, 291-301.

27. Langner, J.A.; Zanon, A.J.; Streck, N.A.; Reiniger, L.R.S.; Kaufmann, M.P.; Alves, A.F. Maize: Key agricultural crop in food security and sovereignty in a future with water scarcity. Rev. Bras. Eng. Agríc. Ambient. 2019, 23, 648-654. [CrossRef]

28. Shiferaw, B.; Prasanna, B.; Hellin, J.; Bänziger, M. Crops that feed the world 6. Past successes and future challenges to the role played by maize in global food security. Food Secur. 2011, 3, 307-327. [CrossRef]

29. Khan, W.U.D.; Aziz, T.; Maqsood, M.A.; Farooq, M.; Abdullah, Y.; Ramzani, P.M.A.; Bilal, H.M. Silicon nutrition mitigates salinity stress in maize by modulating ion accumulation, photosynthesis, and antioxidants. Photosynthetica 2018, 56, 1047-1057. [CrossRef]

30. Iqbal, S.; Hussain, S.; Qayyaum, M.A.; Ashraf, M. The response of maize physiology under salinity stress and its coping strategies. In Plant Stress Physiology; IntechOpen: London, UK, 2020. [CrossRef]

31. Kaya, C.; Tuna, L.; Higgs, D. Effect of silicon on plant growth and mineral nutrition of maize grown under water-stress conditions. J. Plant Nutr. 2006, 29, 1469-1480. [CrossRef]

32. Rojas-Tapias, D.; Moreno-Galván, A.; Pardo-Díaz, S.; Obando, M.; Rivera, D.; Bonilla, R. Effect of inoculation with plant growth-promoting bacteria (PGPB) on amelioration of saline stress in maize (Zea mays). Appl. Soil Ecol. 2012, 61, $264-272$. [CrossRef]

33. Li, H.Q.; Jiang, X.W. Inoculation with plant growth-promoting bacteria (PGPB) improves salt tolerance of maize seedling. Russ. J. Plant Physiol. 2017, 64, 235-241. [CrossRef]

34. Rafiq, K.; Akram, M.S.; Shahid, M.; Qaisar, U.; Rashid, N. Enhancement of salt tolerance in maize (Zea mays L.) using locally isolated Bacillus sp. SR-2-1/1. Biologia 2020, 75, 1425-1436. [CrossRef] 
35. Lee, J.I.; Kong, C.S.; Jung, M.E.; Hong, J.W.; Lim, S.Y.; Seo, Y. Antioxidant activity of the halophyte Limonium tetragonum and its major active components. Biotechnol. Bioprocess Eng. 2011, 16, 992. [CrossRef]

36. Kang, S.M.; Asaf, S.; Khan, A.L.; Khan, A.; Mun, B.G.; Khan, M.A.; Gul, H.; Lee, I.J. Complete genome sequence of Pseudomonas psychrotolerans CS51, a plant growth-promoting bacterium, under heavy metal stress conditions. Microorganisms $2020,8,382$. [CrossRef]

37. Asaf, S.; Khan, A.; Khan, M.; Imran, Q.M.; Yun, B.W.; Lee, I.J. Osmoprotective functions conferred to soybean plants via inoculation with Sphingomonas sp. LK11 and exogenous trehalose. Microbiol. Res. 2017, 205, 135-145. [CrossRef] [PubMed]

38. Asaf, S.; Khan, M.; Khan, A.; Waqas, M.; Shahzad, R.; Kim, A.Y.; Kang, S.M.; Lee, I.J. Bacterial endophytes from arid land plants regulate endogenous hormone content and promote growth in crop plants: An example of Sphingomonas sp. and Serratia marcescens. J. Plant Interact. 2017, 12, 31-38. [CrossRef]

39. Khan, M.A.; Hamayun, M.; Iqbal, A.; Khan, S.A.; Hussain, A.; Asaf, S.; Khan, A.L.; Yun, B.-W.; Lee, I.-J. Gibberellin application ameliorates the adverse impact of short-term flooding on Glycine max L. Biochem. J. 2018, 18, 2893-2905. [CrossRef] [PubMed]

40. Khan, M.A.; Khan, A.L.; Imran, Q.M.; Asaf, S.; Lee, S.U.; Yun, B.W.; Hamayun, M.; Kim, T.H.; Lee, I.J. Exogenous application of nitric oxide donors regulates short-term flooding stress in soybean. PeerJ 2019, 7, e7741. [CrossRef]

41. Jan, R.; Khan, M.A.; Asaf, S.; Lee, I.J.; Bae, J.S.; Kim, K.M. Overexpression of OsCM alleviates BLB stress via phytohormonal accumulation and transcriptional modulation of defense-related genes in Oryza sativa. Sci. Rep. 2020, 10, 19520. [CrossRef]

42. Jan, R.; Khan, M.A.; Asaf, S.; Lee, I.J.; Kim, K.M. Overexpression of OsF3H modulates WBPH stress by alteration of phenylpropanoid pathway at a transcriptomic and metabolomic level in Oryza sativa. Sci. Rep. 2020, 10, 14685. [CrossRef] [PubMed]

43. Adhikari, B.; Dhungana, S.K.; Ali, M.W.; Adhikari, A.; Kim, I.-D.; Shin, D.H. Resveratrol, total phenolic and flavonoid contents, and antioxidant potential of seeds and sprouts of Korean peanuts. Food Sci. Biotechnol. 2018, 27, 1275-1284. [CrossRef]

44. Adhikari, A.; Lee, K.E.; Khan, M.A.; Kang, S.M.; Adhikari, B.; Imran, M.; Jan, R.; Kim, K.M.; Lee, I.J. Effect of Silicate and Phosphate Solubilizing Rhizobacterium Enterobacter ludwigii GAK2 on Oryza sativa L. under Cadmium Stress. J. Microbiol. Biotechnol. 2020, 30, 118-126. [CrossRef] [PubMed]

45. Jan, R.; Khan, M.A.; Asaf, S.; Lee, I.J.; Kim, K.M. Metal resistant endophytic bacteria reduces cadmium, nickel toxicity, and enhances expression of metal stress related genes with improved growth of Oryza sativa, via regulating its antioxidant machinery and endogenous hormones. Plants 2019, 8, 363. [CrossRef] [PubMed]

46. Zörb, C.; Geilfus, C.M.; Dietz, K.J. Salinity and crop yield. Plant Biol. 2019, 21, 31-38. [CrossRef] [PubMed]

47. Rezakhani, L.; Motesharezadeh, B.; Tehrani, M.M.; Etesami, H.; Mirseyed Hosseini, H. Phosphate-solubilizing bacteria and silicon synergistically augment phosphorus (P) uptake by wheat (Triticum aestivum L.) plant fertilized with soluble or insoluble P source. Ecotoxicol. Environ. Saf. 2019, 173, 504-513. [CrossRef]

48. Yue, Z.; Shen, Y.; Chen, Y.; Liang, A.; Chu, C.; Chen, C.; Sun, Z. Microbiological insights into the stress-alleviating property of an endophytic bacillus altitudinis wr10 in wheat under low-phosphorus and high-salinity stresses. Microorganisms $2019,7,508$. [CrossRef]

49. Khan, M.A.; Asaf, S.; Khan, A.L.; Jan, R.; Kang, S.M.; Kim, K.M.; Lee, I.J. Extending thermotolerance to tomato seedlings by inoculation with SA1 isolate of Bacillus cereus and comparison with exogenous humic acid application. PLoS ONE 2020, 15, e0232228. [CrossRef]

50. Khan, M.A.; Asaf, S.; Khan, A.L.; Jan, R.; Kang, S.M.; Kim, K.M.; Lee, I.J. Thermotolerance effect of plant growth-promoting Bacillus cereus SA1 on soybean during heat stress. BMC Microbiol. 2020, 20, 175. [CrossRef]

51. Verma, V.; Ravindran, P.; Kumar, P.P. Plant hormone-mediated regulation of stress responses. BMC Plant Biol. 2016, 16, 86. [CrossRef]

52. Tiwari, S.; Prasad, V.; Chauhan, P.S.; Lata, C. Bacillus amyloliquefaciens Confers Tolerance to Various Abiotic Stresses and Modulates Plant Response to Phytohormones through Osmoprotection and Gene Expression Regulation in Rice. Front. Plant Sci. 2017, 8. [CrossRef]

53. Curá, J.A.; Franz, D.R.; Filosofía, J.E.; Balestrasse, K.B.; Burgueño, L.E. Inoculation with azospirillum sp. and herbaspirillum sp. bacteria increases the tolerance of maize to drought stress. Microorganisms 2017, 5, 41. [CrossRef]

54. Asaf, S.; Hamayun, M.; Khan, A.L.; Waqas, M.; Khan, M.A.; Jan, R.; Lee, I.J.; Hussain, A. Salt tolerance of Glycine max.L induced by endophytic fungus Aspergillus flavus CSH1, via regulating its endogenous hormones and antioxidative system. Plant Physiol. Biochem. 2018, 128, 13-23. [CrossRef]

55. Kiribuchi, K.; Jikumaru, Y.; Kaku, H.; Minami, E.; Hasegawa, M.; Kodama, O.; Seto, H.; Okada, K.; Nojiri, H.; Yamane, H. Involvement of the basic helix-loop-helix transcription factor RERJ1 in wounding and drought stress responses in rice plants. Biosci. Biotechnol. Biochem. 2005, 69, 1042-1044. [CrossRef]

56. Heidari, M.; Golpayegani, A. Effects of water stress and inoculation with plant growth promoting rhizobacteria (PGPR) on antioxidant status and photosynthetic pigments in basil (Ocimum basilicum L.). J. Saud. Soc. Agric. Sci. 2012, 11, 57-61. [CrossRef]

57. Gusain, Y.S.; Singh, U.; Sharma, A. Bacterial mediated amelioration of drought stress in drought tolerant and susceptible cultivars of rice (Oryza sativa L.). Afr. J. Biotechnol. 2015, 14, 764-773.

58. Vardharajula, S.; Zulfikar Ali, S.; Grover, M.; Reddy, G.; Bandi, V. Drought-tolerant plant growth promoting Bacillus spp.: Effect on growth, osmolytes, and antioxidant status of maize under drought stress. J. Plant Interact. 2011, 6, 1-14. [CrossRef]

59. Li, Y.T.; Zhang, W.J.; Cui, J.J.; Lang, D.Y.; Li, M.; Zhao, Q.P.; Zhang, X.H. Silicon nutrition alleviates the lipid peroxidation and ion imbalance of Glycyrrhiza uralensis seedlings under salt stress. Acta Physiol. Plant. 2016, 38, 96. [CrossRef] 
60. Liang, Y.; Hua, H.; Zhu, Y.G.; Zhang, J.; Cheng, C.; R $\div$ mheld, V. Importance of plant species and external silicon concentration to active silicon uptake and transport. New Phytol. 2006, 172, 63-72. [CrossRef] [PubMed]

61. Waqas, M.; Khan, A.L.; Kamran, M.; Hamayun, M.; Kang, S.M.; Kim, Y.H.; Lee, I.J. Endophytic fungi produce gibberellins and indoleacetic acid and promotes host-plant growth during stress. Molecules 2012, 17, 10754-10773. [CrossRef] [PubMed] 